\title{
Karakteristik dan motivasi penyandang disabilitas sebagai karyawan di nusa dua beach hotel
}

\author{
Apriliana Devitasari ${ }^{1)}$, I Gusti Ngurah Widyatmaja ${ }^{2)}$ Putu Ratih Pertiwi ${ }^{3)}$ \\ ${ }^{1}$ Program Studi Diploma IV Pariwisata, Fakultas Pariwisata, Universitas Udayana, J1. Dr. Goris \\ Nomor 7 Denpasar, Bali 80232, Telp/Fax : (0361) 223798 \\ email : aprildevi68@gmail.com ${ }^{1}$
}

\begin{abstract}
Abstrak
Pa da penelitian ini dilatarbelakangioleh a danya kurangnya perhatian peru sahaan di Kabupaten Badung dalam menyerap tenaga kerja penyandang disabilitas serta keragaman penempatan kerja dan perbedaan jenis disabilitas pada karyawan di Nusa Dua Beach Hotel and Spa yang memiliki ka rakte ristik pekerjaan yang berbeda adanya keragaman ini memberikan peran dalam melakukan pekerjaan. Sela in kara kteristik, motivasi penyandang disabilitas mendukung keinginan penyandang disabilitas u n tuk bekerja pada suatu perusahaan. Aturan yang diberikan oleh pemerintah melalui Undang-Undang Nomor 8 tah un 2016 tentang Penyandang Disabilitas dilakukan oleh Nusa Dua Beach Hotel and Spa dalam bentuk mempekerjakan penyandang disabilitas sebagai karyawan. Tujuan dari penelitian ini adalah untuk mengetahui karakteristik darikaryawan disabilitas diNusa Dua Beach Hotel and Spa, un tuk m engetahui motivasi kerja dari karyawan disabilitas di Nusa Dua Beach Hotel and Spa, untuk mengetahui faktor penghambat dan pendukung karyawan disabilitas selamabekerja di Nusa Dua Beach Hotel and Spa. Meto de yang digunakan dalam penelitian ini adalah deskriptif kualitatif dengan mengum pulkan dan menyatukan informasi da ta dariidentifikasi data mentah yang kemudian hasil analisa akan dilakukan in terpreta si data denga m mengumpulkan kesimpulan dari data yang dikumpulkan kemu dian dikembangkan dengan teori y ang di dapat. Pengumpulan data dilakukan dengan observasi, studi literatur, penyebaran kuesioner, dokumentasi dan wa wancara mendalam. Hasildari a nalisa data menyatakan bahwa motiv asi instrin sik dan motivasi ekstrinsik berperan kinerja karyawan terutama dalam berprestasi, karakteristik sosiodemografis dan karakteristik pekerjaan berperan dalam kesesuaian pekerjaan dengan karakteristik karyawan dan produktivitas kerja karyawan. Faktor pendukung karyawan penyandang disa bilit a s dalam bekerja sala $\mathrm{h}$ satunya adalah prestasi darikaryawan. Faktor penghambat dalam bekerja sa lah sa tunya a dalah rotasi pekerjaan.
\end{abstract}

Kata Kunci: Karakteristik, Motivasi, Penyandang Disabilitas.

\begin{abstract}
This research is motivated by the lack of company a ttention in Badung Regency which absorbing workers with disabilities and the diversity of work placements also the different types of disabilities among employees at Nusa Dua Beach Hotel and Spa which have differentjob characteristics. The rules given by the Indonesia government through Law No. 8 of 2016 concerning Persons with Disabilities are carried out by the Nusa Dua Beach Hotel and Spa in the form of employing people with disabilities. The purpose of this study was to determine the characteristics of employees with disabilities at the Nusa Dua Beach Hotel and Spa, to determine the work motivation of employees with disabilities, to determine the inhibiting and supporting factors of disability em ployees while working. The method used in this resea rch is descriptive qualitative by collecting and combining data information from the identification of raw data. The results of the analy sis will be interpreted by collecting data from the data collected and then developed with the theory obtain ed. Da ta collection is done by observation, a study of litera ture, distributing questionnaires, documentation and indepth interviews. The results of the data a nalysis state that intrinsic motivation and extrinsic motivation play a role in employee performance, especially in achievement, sociodemogra phic characteristics and job characteristics play a role in the suitability of work with employee characteristics and employee work productivity. One of the supporting factors for em ployees with disabilities in working is the achievement of employees. One of the inhibiting factors at work is job rotation.
\end{abstract}

Keyword : Characteristic, Motivation, People with Disabilities 


\section{PENDAHULUAN}

Peran manusia sebagai sumber daya pada industri pariwisata turut mendukung keberadaan akomodasi seperti industri perhotelan. Perhotelan adalah bidang usaha yang berkembang seiring dengan kemajuan sektor pariwisata. Tuntutan para pelancong yang ingin mendapatkan layanan akomodasi sesuai permintaan mendorong usaha hotel terus meluas, baik secara kuantitatif maupun kualitatif. Pada saat ini, perhotelan tidak hanya terdiri dari bisnis tradisional melainkan telah berubah secara signifikan menjadi sebuah industri yang peranannya sangat menentukan bagi internasionalisasi usaha perjalanan, kesejahteraan ekonomi dan juga peningkatan transportasi baik darat, laut maupun udara. Oleh karena itu, peran manusia sebagai sumber daya utama dalam industri perhotelan sangat penting keberadaany a, peran ini untuk memenuhi tenaga sumber daya manusia pada pergerakan industri perhotelan. Bali merupakan salah satu provinsi yang menyerap banyak tenaga sumber daya manusia terutama dalam industri Perhotelan, menurut Causa Iman Kepala Perwakilan Bank Indonesia Provinsi Bali mengatakan "untuk tahun 2018 lapangan usaha penyumbang terbesar masih di akomodasi, makan dan minum, pada Agustus 2017 lalu, sektor pariwisata menyerap tenaga kerja terbanyak yaitu 760 ribu (31,7 persen) dari total penduduk yang bekerja di Bali” (NusaBali.com).

Dalam perkembangan saat ini peran sumber daya manusia dalam bekerja di Industri Perhotelan juga memberi ruang pada penyandang disabilitas untuk mendapatkan pekerjaan yang sama dengan non penyandang disabilitas. Hal ini berlaku dengan dibuktikan adanya sumber daya manusia penyandang disabilitas yang diberikan hak dalam bekerja di industri yang sama dengan sumber daya manusia non penyandang disabilitas. Hal ini diperkuat dengan aturan pemerintah dalam Undang-Undang no 8 tahun 2016 tentang tenaga kerja penyandang disabilitas yang tertera pada Pasal 53 ayat 1 yaitu "Pemerintah, Pemerintah Daerah, Badan Usaha Milik Negara, dan Badan Usaha Milik Daerah wajib mempekerjakan paling sedikit 2\% (dua persen) penyandang disabilitas dari jumlah pegawai atau pekerja" dan Pasal 53 ayat 2 yaitu "Perusahaan swasta wajib mempekerjakan paling sedikit 1\% (satu persen) Penyandang Disabilitas dari jumlah pegawai atau pekerja.". Namun, undang-undang dari pemerintah Negara Republik Indonesia ini masih tidak terealisasi dengan baik pada daerah di Indonesia. Pada Kabupaten Badung masih banyak perusahaan yang belum menyerap penyandang disabilitas untuk bekerja di perusahaan mereka, hal ini dipertegas dnegan pernyataan Made Reta selaku Ketua Panitia Khusus rapat disabilitas DPRD Badung, yang mengatakan "masih satu, dua perusahaan yang memiliki kesadaran untuk mempekerjakan penyandang disabilitas pada perusahaan mereka. Kesadaran ini sebagian besar dikarenakan oleh kasihan, hal ini seharusnya tidak boleh, penyandang disabilitas juga harus mendapatkan hak yang sama, dengan adanya undang-undang Perda juga akan diaturd tentang pendidikan dan pemenuhan skill untuk penyandang disabilitas guna memenuhi kebutuhan sumber daya manusia yang sesuai dengan perusahaan, sehingga bukan dipekerjakan karena faktor kasihan". (Bali Tribun). Dengan adanya situasi ini, pemerintah Kabupaten Badung merancang Peraturan Daerah guna adanya pemenuhan penyerapan penyandang disabilitas pada setiap perusahaan di Kabupaten Badung. Undang-undang ini menjadi juga dapat menjadi salah satu dorongan suatu industri untuk mempekerjakan karyawan penyandang disabilitas sehingga tidak dipekerjakan karena kasihan akan tetapi juga diperhitungkan dari kemampuan yang dimiliki.

Dengan adanya undang-undang tersebut diharapkan dapat menjadi salah satu motivasi bagi penyandang disabilitas untuk bekerja pada lingkungan yang sama dengan non penyandang disabilitas. Motivasi ini termasuk dalam motivasi ekstrinsik yaitu motivasi yang berasal dari luar diri seseorang. Motivasi dibagi menjadi 2 (dua) bagian yaitu motivasi instrinsik, motivasi yang berasal dari dalam diri seseorang dan motivasi ekstrinsik, motivasi yang berasal dari luar diri seseorang.

Karakteristik pada seorang karyawan memberikan informasi tentang ciri khas dari karyawan tersebut. Karakteristik dapat membantu pihak manajemen Sumber Daya Manusia untuk mengelola potensi dan kemampuan karyawan yang sesuai dengan karakteristik orang tersebut. Hal 
ini dapat dibantu dengan adanya karakteristik sosiodemografis yang menjelaskan tentang jenis kelamin, usia, latar belakang pekerjaan, pendidikan, jumlah keluarga. Selain karakteristik sosiodemografis, Karakteristik pekerjaan dapat menjadi bahan pertimbangan manajemen Sumber Daya Manusia dalam menganalisa sifat-sifat pekerjaan dari karyawan penyandnag disabilitas untuk dipertimbangkan dalam perancangan pekerjaan. Pentingnya karakteristik dan motivasi dalam bekerja dapat menjelaskan faktor-faktor apa saja yang mendukung dan menghambat karyawan dalam bekerja.

Nusa Dua yang terletak pada Kabupaten Badung merupakan salah satu wilayah di Bali yang dikenal dengan daya tarik wisata pantai yang indah. Selain itu, wilayah Nusa Dua memiliki Kawasan Pariwisata yang dikelola oleh Indonesia Tourism Development Corporation (ITDC), kawasan ini dikenal berisi 17 Hotel Bintang 5 dan 1 hotel bintang 4. Dari 18 hotel di kawasan ITDC ada salah satu hotel yang mendukung aturan pemerintah tentang tenaga kerja penyandang disabilitas yang tercatat dalam Undang-Undang no 8 Tahun 2016. Nusa Dua Beach Hotel and Spa merupakan salah satu hotel yang mempekerjakan karyawan penyandang disabilitas. Keberadaan karyawan disabilitas di hotel ini memiliki kategori disabilitas fisik dan sensorik yaitu :

Tabel 1.1: Jumlah Karyawan Disabilitas Nusa Dua Beach Hotel and Spa

\begin{tabular}{llll}
\hline $\begin{array}{l}\text { Jumlah } \\
\text { penyandang } \\
\text { disabilitas }\end{array}$ & Jenis disabilitas & Jenis Kelamin & Departemen/Bagian \\
\hline 2 Orang & Tuna Wicara & Pria & FnB/Steward \\
\hline 1 Orang & Tuna Wicara & Wanita & FnB/Kitchen \\
\hline 1 Orang & Tuna Rungu & Wanita & Housekeeping/Laundry \\
\hline 1 Orang & Tuna Daksa & Pria & Security/CCTV \\
\hline
\end{tabular}

Sumber: Human Resources Department Nusa Dua Beach Hotel and Spa. 2019.

Dari keragaman penempatan kerja dan perbedaan jenis disabilitas ini memiliki karakteristik pekerjaan yang berbeda dalam menjalani masing-masing tugas, maka hal ini melatarbelakangi penelitian ini dengan judul penelitian "Karakteristik Dan Motivasi Penyandang Disabilitas Sebagai Karyawan Di Nusa Dua Beach Hotel And Spa". Dengan tujuan mengetahui karakteristik dari karyawan penyandang disabilitas, mengetahui motivasi dari karyawan penyandang disabilitas dan mengetahui factor penghambat dan pendukung kinerja karyawan penyandang disabilitas.

Pada penelitian-penelitian sejenis yang memiliki korelasi dengan penelitian ini yaitu Penelitian sebelumnya yang dilakukan oleh Valentini Kalarogyrou. 2012. Dengan judul "People With Disabilities: A New Model Of Productive Labor" . Tujuan dari penelitian ini adalah Untuk mengetahui strategi rekrutmen karyawan disabilitas, keuntungan yang di dapat dari memperkerjakan karyawan disabilitas dan pelajaran yang dapat di hubungkan dengan industri hospitality.

Lokasi penelitian ini bertempat di Walgreens, variabel yang digunakan adalah penyandang disabilitas, teknik pengumpulan data yang digunakan yaitu wawancara langsung dengan kary aw an disabilitas serta manajer Waalgreens dan observasi, teknik analisis data yang digunakan yaitu Teknik Analisis Atlas TI, hasil penelitian menyebutkan banyak industri hospitality yang mempekerjakan karyawan disabilitas namun masih sedikit industri yang memperhatikan khusus cara memperlakukan dan mempekerjakan karyawan disabilitas. Walgreens menggunakan strategi skill komunikasi dalam mengembangkan karyawan disabilitas, selain itu dukungan dari mentor dan skil pemecahan masalah juga berpengaruh dalam mengembangkan karyawan disabilitas.

Penelitian yang kedua oleh Satria Febriantara. 2012 berjudul "Karakteristik Individu, Karakteristik Pekerjaan, Karakteristik Organisasi dan Kepuasan Kerja Pengurus yang Dimediasi 
oleh Motivasi Kerja (Studi pada Pengurus KUD di Kabupaten Sleman). Tujuan penelitian dari penelitian ini adalah mengetahui pengaruh karakteristik individu, karakteristik pekerjaan dan karakteristik organisasi terhadap kepuasan kerja pengurus, mengetahui pengaruh karakteristik individu, karakteristik pekerjaan dan karakteristik organisasi terhadap motivasi kerja pengurus, mengetahui pengaruh motivasi kerja terhadap kepuasan kerja pengurus dan mengetahui pengaruh karakteristik individu, karakteristik pekerjaan dan karakteristik organisasi terhadap kepuasan kerja yang dimediasi oleh motivasi kerja pengurus.

Lokasi penelitian ini bertempat di Koperasi Unit Desa Kabupaten Sleman, variabel yang digunakan adalah Karakteristik Individu, Karakteristik Pekerjaan, Motivasi Kerja dan Karakteristik Organisasi, teknik pengumpulan data yang digunakan yaitu observasi, wawancara terstruktur, kuesioner dan dokumentasi. Teknik analisis data yang digunakan yaitu Structural Equation Model (Moderating SEM) dengan twostep approach, menggunakan AMOS 16.0. Hasil penelitian menyebutkan:

1) Karakteristikindividu, karakteristik pekerjaan dan karakteristik organisasi berp engar uh langsung dan signifikan terhadap kepuasan kerja pengurus.

2) Karakteristik individu, karakteristik pekerjaan dan karakteristik organisasiberp engar uh langsung dan signifikan terhadap motivasi kerja pengurus.

3) Motivasi kerja berpengaruh langsung dan signifikan terhadap kepuasan kerja pengurus.

4) Karakteristik individu, karakteristik pekerjaan dan karakteristik organisasi berp engar uh langsung dan signifikan terhadap kepuasan kerja pengurus yang dimediasi oleh m elalui motivasi kerja pengurus.

Penelitian yang ketiga oleh Yudhi Dwi Prasetyo. 2017 berjudul "Motivasi Kerja Orang Penyandang Disabilitas Yang Berada di YPCM Yogyakarta". Tujuan penelitian dari penelitian ini adalah mengetahui motivasi kerja dari penyandang disabilitas di YPCM Yogyakarta.

Lokasi penelitian ini bertempat di Yayasan Penyandang Cacat Mandiri Yogyakarta, variabel yang digunakan adalah motivasi kerja, teknik pengumpulan data yang digunakan yaitu observasi menggunakan pendekatan humanistik, wawancara dan dokumentasi. Teknik analisis data yang digunakan yaitu analisis data kualitatif, hasil penelitian menyebutkan orang-orang yang memiliki kebutuhan khusus atau difabel akan lebih maju dan berkembang motivasinya jika diperoleh dari lingkungan kerja, tempat kerja, dan lainnya yang memberi motivasi kepada individu yang memiliki difabel tersebut untuk bisa menjalani sehari-harinya untuk lebih baik.

Berdasarkan penelitian-penelitian sebelumnya yang dikorelasikan dengan penelitian ini terdapat beberapa hal yang perlu ditekankan perbedaannya terdapat pada objek penelitian yang semua tidak berlokasi pada industri perhotelan dan pada penelitian ketiga terfokus pada yayasan yang ada di Yogyakarta, sedangkan penelitian ini terfokus pada industri perhotelan. Pada penelitian kedua juga mempunyai perbedaan yaitu penelitian ini adalah jenis penelitian deskriptif kuantitif dan hanya menggunakan kuisioner untuk pencarian data, hal ini berbeda dengan penelitian pertama, ketiga dan penelitian saat ini.

\section{METODE PENELITIAN}

Lokasi Penelitian ini berada di Nusa Dua Beach Hotel and Spa yang merupakan salah satu diantara hotel berbintang lima di kawasan pariwisata Nusa Dua. Hotel ini berlokasi di Kawasan Pariwisata Nusa Dua Lot North 4 Nusa dua, Bali, Indonesia. Hotel ini dipilih sebagai lokasi penelitian dikarenakan tiga hal, sebagai berikut:

1. Nusa Dua Beach Hotel and Spa merupakan hotel pertama di Kawasan Pariwisata Nusa Dua yang di dirikan pada tahun 1982 dan diresmikan pengoperasianya pada tanggal $28 \mathrm{Mei}$ 1983 oleh mantan Presiden Soeharto. 
2. Keunikan hotel yang mengusung tema "Authentically Bali" sehingga arsitektur dan budaya hotel mempertahankan keaslian Bali yang diberikan kepada tamu, serta sajian makanan di restaurant yang bersertifikat halal.

3. Nusa Dua Beach Hotel and Spa mendukung program pemerintah dengan mempekerjakan penyandnag disabilitas sebagai karyawan di Nusa Dua Beach Hotel and Spa, dengan dibuktikan penghargaan pada bulan April 2019 di Jakarta dari Kementerian Ketenagakerjaan Republik Indonesia sebagai salah satu hotel yang mempekerjakan karyawan penyandang disabilitas.

\subsection{Definisi Operasional Variabel}

Definisi Operasional Variabel bertujuan untuk menjelaskan variabel-variabel yang akan diteliti untuk membatasi ruang lingkup permasalahan penelitian, variabel dalam penelitian ini adalah karakteristik dan motivasi kerja, maka perlu dijelaskan variabel-variabel yang terkait dalam penelitian ini, yaitu :

\subsubsection{Karakteristik}

Karakteristik yang dimaksud dalam penelitian ini adalah ciri khas pada suatu individu yang ditinjau dari segi sosiodemografis dan pekerjaan. Karakteristik berdasarkan sosiodemografis untuk mengetahui karakteristik karyawan yang mendukung karakteristik secara pribadi. Sedangkan, pada karakteristik pekerjaan menjelaskan hal yang mendukung karakter karyawan disabilitas dalam melakukan pekerjaan. Pada bagian karakteristik dibatasi dengan variabel karakteristik yang terbagi menjadi karakteristik sosiodemografis dan karakteristik pekerjaan, sehingga penelitian lebih terperinci :

Tabel 1.3: Definisi Operasional Variabel Karakteristik

\begin{tabular}{|c|c|c|c|c|}
\hline \multirow{3}{*}{$\begin{array}{l}\text { Variabel } \\
\text { Karakteristik } \\
\text { Sosiodemografis }\end{array}$} & Indikator & Sub Indikator & Sumber & \\
\hline & \multirow[t]{5}{*}{ Umur } & $0-14$ tahun & \multirow{23}{*}{$\begin{array}{l}\text { Suwena, } \\
\text { (2017) }\end{array}$} & \multirow[t]{22}{*}{ Widyatmaja } \\
\hline & & 15-24 tahun & & \\
\hline & & 25-44 tahun & & \\
\hline & & 45-64 tahun & & \\
\hline & & $>65$ tahun & & \\
\hline & \multirow[t]{2}{*}{ Jenis Kelamin } & Laki-Laki & & \\
\hline & & Perempuan & & \\
\hline & Tingkat & Tidak tamat SD & & \\
\hline & \multirow{6}{*}{ Pendidikan } & SD & & \\
\hline & & SLTP & & \\
\hline & & SMU & & \\
\hline & & Diploma & & \\
\hline & & Sarjana (S1) & & \\
\hline & & Pasca Sarjana $(\mathrm{S} 2, \mathrm{~S} 3)$ & & \\
\hline & \multirow[t]{3}{*}{ Status Perkawinan } & Belum menikah & & \\
\hline & & Menikah & & \\
\hline & & Cerai & & \\
\hline & \multirow{6}{*}{$\begin{array}{lr}\text { Jumlah } & \text { Anggota } \\
\text { keluarga } & \text { dan } \\
\text { komposisinya }\end{array}$} & 1 orang & & \\
\hline & & Beberapa orang, tanpa & & \\
\hline & & $\begin{array}{l}\text { anak usia di bawah } 17 \\
\text { tahun }\end{array}$ & & \\
\hline & & Beberapa orang, dengan & & \\
\hline & & anak (beberapa anak) di & & \\
\hline & & bawah 17 tahun & & \\
\hline & Tipe Keluarga & Belum menikah & & \\
\hline
\end{tabular}




\begin{tabular}{|c|c|c|c|}
\hline & & $\begin{array}{l}\text { Menikah, belum punya } \\
\text { anak } \\
\text { Menikah, anak usia <6 } \\
\text { tahun } \\
\text { Menikah, anak usia 6-17 } \\
\text { tahun } \\
\text { Menikah, anak usia 18- } \\
25 \text { tahun } \\
\text { Menikah, anak usia }>25 \\
\text { tahun, masih tinggal } \\
\text { dengan orang tua } \\
\text { Menikah, anak usia }>25 \\
\text { tahun, tidak tinggal } \\
\text { dengan orang tua(empty } \\
\text { nest) }\end{array}$ & \\
\hline \multirow[t]{5}{*}{$\begin{array}{l}\text { Karakteristik } \\
\text { Pekerjaan }\end{array}$} & Identifikasi Tugas & $\begin{array}{lll}\text { a. } & \text { Hasil dari } \\
& \text { pekerjaan } \\
\text { b. } & \text { Prestasi yang di } \\
\text { dapat dari } & \text { pekerjaan } \\
& \\
\end{array}$ & Any Setiawati (2005:44) \\
\hline & $\begin{array}{l}\text { Variasi } \\
\text { Keterampilan }\end{array}$ & $\begin{aligned} & \text { a. } \text { Pekerjaan yang } \\
& \text { dilakukan } \\
& \text { b. } \text { Ragam } \\
& \text { pekerjaan yang } \\
& \text { dilakukan } \\
& \text { c. } \text { Cara melakukan } \\
& \text { pekerjaan } \\
& \text { d. Rotasi pekerjaan }\end{aligned}$ & \\
\hline & Signifikansi Tugas & $\begin{array}{l}\text { a. } \\
\text { Pentingnya } \\
\text { pekerjaan bagi } \\
\text { karyawan } \\
\text { b. Pengaruh } \\
\text { pekerjaan untuk } \\
\text { karyawan } \\
\end{array}$ & \\
\hline & Otonomi & $\begin{array}{ll}\text { a. } & \text { Strategi pribadi } \\
\text { yang digunakan } \\
\text { dalam } \\
\text { melakukan tugas } \\
\text { b. } \\
\text { Improvisasi } \\
\text { tugas selain dari } \\
\text { Standart } \\
\text { Operasional } \\
\text { Prosedur } \\
\end{array}$ & \\
\hline & Umpan Balik & $\begin{array}{ll}\text { a. } & \text { Penilaian baik } \\
& \text { atau tidak tugas } \\
& \text { yang sudah } \\
& \text { dilakukan } \\
\text { b. } & \text { Informasi baik } \\
& \text { buruk tentang } \\
& \text { pekerjaan yang } \\
& \text { sudah dilakukan }\end{array}$ & \\
\hline
\end{tabular}


Dalam penelitian ini, motivasi yang dimaksud membahas bagaimana cara mengarahkan daya dan potensi karyawan agar mau bekerja sama secara produktif mencapai dan mewujudkan tujuan yang telah ditentukan oleh hotel. Untuk variabel motivasi dibatasi dengan motivasi intrinsik yang membahas dorongan dari dalam terjadinya motivasi kerja karyawan disabilitas, sebagai berikut:

Tabel 1.4 : Definisi Operasional Variabel Motivasi

\begin{tabular}{|c|c|c|c|}
\hline Variabel & Indikator & Sub Indikator & Sumber \\
\hline \multirow{7}{*}{$\begin{array}{l}\text { Motivasi } \\
\text { Intrinsik }\end{array}$} & Achievment & a. Kualitas Kerja & \multirow{7}{*}{$\begin{array}{l}\text { Herzberg, dikutip oleh Luthans } \\
\text { (2011) }\end{array}$} \\
\hline & (keberhasilan) & $\begin{array}{l}\text { b. Bersemangat untuk } \\
\text { berprestasi }\end{array}$ & \\
\hline & $\begin{array}{l}\text { Recognition } \\
\text { (Pengakuan) }\end{array}$ & $\begin{array}{l}\text { a. Rasa ingin diakui } \\
\text { keberadaanya }\end{array}$ & \\
\hline & & $\begin{array}{l}\text { b. Rasa ingin diakui } \\
\text { kemampuannya }\end{array}$ & \\
\hline & $\begin{array}{l}\text { Responsiblity } \\
\text { (Tanggungjawab) }\end{array}$ & $\begin{array}{l}\text { a. Rasa tanggung jawab } \\
\text { dalam pekerjaan } \\
\text { b. Resiko dalam bekerja }\end{array}$ & \\
\hline & $\begin{array}{l}\text { Advencement } \\
\text { (Pengembangan) }\end{array}$ & $\begin{array}{l}\text { a. Pelatihan-pelatihan } \\
\text { yang diberikan untuk } \\
\text { menunjang kualitas } \\
\text { karyawan } \\
\end{array}$ & \\
\hline & $\begin{array}{lr}\begin{array}{l}\text { Work it } \\
\text { (pekerjaan }\end{array} & \text { Self } \\
\text { sendiri) } & \text { itu } \\
& \end{array}$ & $\begin{array}{l}\text { a. Rasa memiliki dalam } \\
\text { bekerja } \\
\text { b. Sesuai dengan minat } \\
\text { dan kemampuan diri } \\
\text { c. Merasakan pentingnya } \\
\text { bekerja } \\
\text { d. Bekerja atas keinginan } \\
\text { sendiri }\end{array}$ & \\
\hline \multirow[t]{6}{*}{$\begin{array}{l}\text { Motivasi } \\
\text { Ekstrinsik }\end{array}$} & $\begin{array}{l}\text { Policy and } \\
\text { Administration } \\
\text { (Kebijakan dan } \\
\text { Administrasi) } \\
\end{array}$ & $\begin{array}{llr}\text { a. } & \text { Melakukan } & \text { pekerjaan } \\
\text { berdasarkan } & \text { SOP } \\
& \text { karyawan Hotel } & \end{array}$ & \multirow[t]{6}{*}{$\begin{array}{l}\text { Herzberg, dikutip oleh Luthans } \\
\text { (2011) }\end{array}$} \\
\hline & $\begin{array}{l}\text { Quality Supervisor } \\
\text { (Kualitas } \\
\text { Supervisi) }\end{array}$ & $\begin{array}{ll}\text { a. } & \text { Peran HRD dalam } \\
\text { mengawasi } & \\
\text { perkembangan } & \\
\text { karyawan } & \\
\end{array}$ & \\
\hline & $\begin{array}{l}\text { Interpersonal } \\
\text { Relation } \\
\text { (Hubungan Antar } \\
\text { Pribadi) }\end{array}$ & $\begin{array}{l}\text { a. Hubungan karyawan } \\
\text { disabilitas dengan } \\
\text { karyawan lainnya } \\
\text { b. Kemampuan } \\
\text { komunikasi dan relasi } \\
\text { antar karyawan } \\
\end{array}$ & \\
\hline & $\begin{array}{l}\text { Working Condition } \\
\text { (Kondisi kerja) }\end{array}$ & $\begin{array}{l}\text { b. Lingkungan kerja yang } \\
\text { mendukung aktivitas } \\
\text { pekerjaan karyawan }\end{array}$ & \\
\hline & & $\begin{array}{l}\text { c. Alat khusus untuk } \\
\text { membantu aktivitas } \\
\text { pekerjaan karyawan } \\
\text { disabilitas }\end{array}$ & \\
\hline & Wages (Upah) & $\begin{array}{l}\text { a. Kesesuaian upah yang } \\
\text { diberikan kepada } \\
\text { karyawan disabilitas }\end{array}$ & \\
\hline
\end{tabular}


Sumber : Hasil modifikasi, 2019

\subsubsection{Faktor Penghambat dan Pendukung}

Faktor pendukung merupakan hal yang mendukung proses kerja karyawan penyandang disabilitas di Nusa Dua Beach Hotel and Spa, sedangkan faktor penghambat merupakan hambatan yang terjadi selama bekerja di Nusa Dua Beach Hotel and Spa. Faktor pendukung dan penghambat dalam penelitian ini dibagi menjadi faktor individu dan faktor manajemen, yang dirangkum sebagai berikut :

1). Faktor Individual sendiri.

Dalam penelitian ini, faktor individual merupakan faktor yang berasal dari diri pekerja itu

2). Faktor Manajemen

Dalam penelitian ini, faktor manajemen merupakan faktor yang berasal dari perusahaan atau industri tempat karyawan bekerja, yaitu lingkungan Nusa Dua Beach Hotel and Spa.

\section{Jenis dan Sumber Data}

\subsubsection{Jenis Data}

Dalam penelitian ini, jenis data yang digunakan untuk memperlengkapi penelitian ini adalah sebagai berikut :

\section{1) Data Kualitatif}

Data yang tidak dinyatakan dengan angka, melainkan berupa informasi atau keterangan yang berhubungan dengan permasalahan yang diteliti. Dalam penelitian ini meliputi informasi tentang sejarah hotel, struktur organisasi di hotel, serta informasi tentang motivasi kerja karyaw an disabilitas di Nusa Dua Beach Hotel and Spa.

\section{1) Data Kuantitatif}

Data yang berupa angka-angka seperti jumlah karyawan disabilitas di Nusa Dua Beach Hotel and Spa.

\subsubsection{Sumber Data}

Berdasarkan sumbernya, data yang digunakan dalam penelitian ini dibedakan menjadi dua, antara lain sebagai berikut :

1) Data primer, yaitu informasi yang diperoleh dari sumber pertama lokasi penelitian yang dilakukan melalui pengamatan langsung (observasi), dan wawancara dengan karyawan disabilitas di Nusa Dua Beach Hotel and Spa. Seperti data langsung yang diberikan oleh karyawan disabilitas di Nusa Dua Beach Hotel and Spa mengenai tipe pekerjaan yang sesuai dengan karakteristik.

2) Data sekunder, yaitu informasi yang diperoleh bukan dari sumber asli yang menjadi sasaran penelitian. Dalam penelitian ini adalah data pada dokumen-dokumen dan catatan yang berasal dari Human Resources Department terkait karyawan disabilitas di Nusa Dua Beach Hotel and Spa.

\subsection{Teknik Pengumpulan Data} berikut :

Data dalam penelitian ini diperoleh melalui beberapa teknik pengumpulan data sebagai

\section{1) Observasi}

Metode observasi adalah cara mengumpulkan data melalui pengamatan langsung terhadap gejala fisik objek penelitian. Dalam penelitian ini kegiatan observasi dilakukan untuk melihat sumber informasi di hotel. Kegiatan penelitian ini juga disertai dengan mengambil foto dari lokasi penelitian dan segala informasi tentang gambaran umum hotel.

2) Wawancara Mendalam

Dalam penelitian ini menggunakan metode wawancara mendalam (in-depth interview) merupakan proses menggali informasi secara mendalam, terbuka, dan bebas dengan masalah dan 
fokus penelitian dan diarahkan pada pusat penelitian dan dilakukan dengan adanya daftar pertanyaan yang telah dipersiapkan sebelumnya (Moleong,2007:186). Untuk wawancara terhadap karyawan Tuna Rungu dan Tuna Wicara menggunakan perantara dari penerjemah Tuli dan Dengar yang memperdalam hasil dari kuisioner yang diberikan kepada penyandang disabilitas.

3) Kuisioner

Teknik pengumpulan data ini untuk dasar jawaban sebelum ditanyakan dengan wawancara mendalam. Karena keterbatasan bahasa oleh penyandang disabilitas Tuna Rungu. Penggunaan kuisioner pada penyandang disabilitas Tuna Rungu difasilitasi dengan penerjemah Tuli dan Dengar dari Blai Deaf Community yang disesuaikan dengan makna dari pertanyaan pada kuisioner.

4) Dokumentasi

Dokumentasi yaitu suatu cara pengumpulan data yang dilakukan dengan cara memperoleh data mengenai hal-hal atau variabel yang diteliti. Teknik dokumentasi yang diamati bukan benda hidup tapi benda mati. Seperti foto kegiatan kerja karyawan dan kondisi lingkungan kerja karyawan disabilitas.

5) Studi Kepustakaan

Teknik pengumpulan data ini dengan mengadakan studi penelaah terhadap buku-buku, literatur-literatur sebagai informasi data dan cara memecahkan permasalahan.

\subsection{Teknik Penentuan Informan}

Informan adalah orang yang bisa memberi informasi tentang situasi dan kondisi latar penelitian. Adapun teknik penentuan informan dalam penelitian ini menggunakan teknik purposive sampling. Menurut Sugiono (2011:85). Teknik Purposive Sampling yaitu teknik pengambilan sample didasarkan atas tujuan tertentu dimana orang yang dipilih benar-benar memiliki kriteria sebagai sampel. Informan dibagi menjadi dua kategori yaitu informan pangkal dan informan kunci. Informan pangkal adalah informan utama yang akan memberikan petunjuk untuk mendapatkan data yang lebih lengkap dan efektif sesuai dengan kebutuhan penelitian. Sedangkan, informan kunci adalah informan yang akan memberikan informasi lebih spesifik tentang data yang dibutuhkan. Informan pangkal dalam penelitian ini adalah Human and Resources Manager, dan informan kunci dalam penelitian ini adalah Training Manager.

\subsection{Teknik Penentuan Sampel}

Sampel merupakan bagian dari jumlah dan karakteristik yang dimiliki oleh populasi tersebut. Sampel yang digunakan dalam penelitian ini didapat dengan menggunakan teknik sampling jenuh. Teknik ini merupakan teknik penentuan sampel jika semua populasi digunakan sebagai sampel. Dimana populasi sebanyak 4 karyawan penyandang disabilitas digunakan sebagai sampel dalam penelitian ini.

\subsection{Teknik Analisis Data}

\subsubsection{Analisis Deskriptif Kualitatif}

Analisis ini merupakan penggambaran umum dari seluruh data yang terkumpul, yang kemudian disusun dalam bentuk tabel dan kalimat yang mudah diipahami. Menurut Sarantakos (1993) dalam analisis data kualitatif dilakukan dengan tiga tahapan, yaitu :

1) Reduksi data

Merupakan proses mengidentifikasi data mentah ( raw data) yang telah diperoleh dengan melakukan langkah summary, pengkodean (coding), dan kategorisasi.

\section{2) Pengorganisasian}

Merupakan proses mengumpulkan atau menyatukan informasi data yang dihasilkan dari identifikasi awal yaitu proses reduksi data. Hasil analisis kemudian dilakukan interpretasi data.

3) Interpretasi data

Merupakan kumpulan kesimpulan dari daftar pertanyaan penelitian yang dikembangkan melalui teori, informasi, dan keilmuan yang di dapat. 


\section{HASIL DAN PEMBAHASAN}

\subsection{Karakteristik Karyawan Disabilitas di Nusa Dua Beach Hotel and Spa.}

Dari data yang diperoleh melalui wawancara langsung dan mendalam terhadap responden, berikut hasil yang diperoleh :

\subsection{Karakteristik Sosiodemografis}

Tabel 1.5 Karakteristik Sosiodemografis Karyawan Penyandang Disabilitas di Nusa Dua Beach Hotel and Spa

\begin{tabular}{|c|c|c|c|c|c|}
\hline $\begin{array}{c}\text { Variabel } \\
\text { Karakteristik } \\
\text { Sosiodemografis }\end{array}$ & $\begin{array}{c}\text { Responden } \\
1\end{array}$ & $\begin{array}{c}\text { Responden } \\
2\end{array}$ & $\begin{array}{c}\text { Responden } \\
3\end{array}$ & $\begin{array}{c}\text { Responden } \\
4\end{array}$ & $\begin{array}{c}\text { Responden } \\
5\end{array}$ \\
\hline Umur & $\begin{array}{l}25-44 \\
\text { Tahun }\end{array}$ & $\begin{array}{l}25-44 \\
\text { Tahun }\end{array}$ & $\begin{array}{l}25-44 \\
\text { Tahun }\end{array}$ & $\begin{array}{l}25-44 \\
\text { Tahun }\end{array}$ & 25-44 Tahun \\
\hline Jenis kelamin & perempuan & Laki-laki & Laki-laki & Perempuan & Laki-laki \\
\hline $\begin{array}{l}\text { Tingkat } \\
\text { pendidikan }\end{array}$ & SMA LB & SMA LB & $\begin{array}{l}\text { D1 Jurusan } \\
\text { Komputer }\end{array}$ & SMA LB & SMA LB \\
\hline $\begin{array}{l}\text { Jumlah anggota } \\
\text { keluarga dan } \\
\text { komposisinya }\end{array}$ & $\begin{array}{l}\text { Beberapa } \\
\text { orang, } \\
\text { tanpa anak } \\
\text { usia di } \\
\text { bawah } 17 \\
\text { tahun }\end{array}$ & $\begin{array}{l}\text { Beberapa } \\
\text { orang, } \\
\text { dengan } \\
\text { anak } \\
\text { (beberapa } \\
\text { anak) di } \\
\text { bawah } 17 \\
\text { tahun }\end{array}$ & 1 orang & $\begin{array}{l}\text { Beberapa } \\
\text { orang, } \\
\text { tanpa anak } \\
\text { usia di } \\
\text { bawah } 17 \\
\text { tahun }\end{array}$ & $\begin{array}{l}\text { Beberapa orang, } \\
\text { dengan anak } \\
\text { (beberapa anak) di } \\
\text { bawah } 17 \text { tahun }\end{array}$ \\
\hline $\begin{array}{l}\text { Status } \\
\text { perkawinan }\end{array}$ & Menikah & $\begin{array}{l}\text { Belum } \\
\text { menikah }\end{array}$ & $\begin{array}{l}\text { Belum } \\
\text { menikah }\end{array}$ & $\begin{array}{l}\text { Belum } \\
\text { menikah }\end{array}$ & Menikah \\
\hline Tipe Keluarga & $\begin{array}{l}\text { Menikah, } \\
\text { belum } \\
\text { punya anak }\end{array}$ & $\begin{array}{l}\text { Belum } \\
\text { menikah }\end{array}$ & $\begin{array}{l}\text { Belum } \\
\text { menikah }\end{array}$ & $\begin{array}{l}\text { Belum } \\
\text { menikah }\end{array}$ & $\begin{array}{l}\text { Menikah, anak } \\
\text { usia <6 tahun }\end{array}$ \\
\hline Jenis kecacatan & $\begin{array}{l}\text { Tuna } \\
\text { Rungu }\end{array}$ & $\begin{array}{l}\text { Tuna } \\
\text { Rungu }\end{array}$ & $\begin{array}{l}\text { Tuna } \\
\text { Daksa }\end{array}$ & $\begin{array}{l}\text { Tuna } \\
\text { Rungu }\end{array}$ & Tuna Rungu \\
\hline
\end{tabular}

Sumber : wawancara mendalam penulis (2019)

Dalam pembahasan karakteristik sosiodemografis ini, dijelaskan variabel dari karakteristik sosiodemografis pada masing-masing responden karyawan disabilitas, Dari data responden yang diperoleh, keseluruhan responden berumur diatas 25 tahun, yaitu umur 27-32 tahun. Latar belakang pendidikan dan jenis kecacatan menjadi bahan pertimbangan untuk penempatan tempat kerja, semua responden memiliki latar belakang sekolah yang sama yaitu pada Sekolah Luar Biasa yang terletak di Kabupaten Badung, dari keseluruhan responden hanya satu responden yang memiliki pendidikan tinggi di atas Sekolah Menengah Atas, yaitu responden yang bekerja pada bagian CCTV. Untuk responden yang memiliki pendidikan paling tinggi Sekolah Menengah Atas rata-rata memiliki jenis pekerjaan yang sama yaitu Steward, Laundry dan Kitchen. Dari hal ini diketahui bahwa pendidikan juga mempeng aruhi posisi pekerjaan yang dijalani oleh karyawan penyandang disabilitas. Selain pendidikan, jenis kecacatan juga mempengaruhi penempatan departemen kerja. Untuk penyandang disabilitas Tuna Rungu ditempatkan di bagian back office yang dalam rentang waktunya jarang bertemu dengan tamu karena menghandle keperluan karyawan bukan tamu. 


\subsection{Karakteristik Pekerjaan}

Tabel 1.6 Karakteristik pekerjaan responden

\begin{tabular}{|c|c|c|c|c|c|c|}
\hline No. & $\begin{array}{c}\text { Variabel } \\
\text { Karakteristik } \\
\text { Pekerjaan }\end{array}$ & $\begin{array}{c}\text { Responden } \\
1\end{array}$ & $\begin{array}{c}\text { Responden } \\
2\end{array}$ & $\begin{array}{c}\text { Responden } \\
3\end{array}$ & $\begin{array}{c}\text { Responden } \\
4\end{array}$ & $\begin{array}{c}\text { Responden } \\
5\end{array}$ \\
\hline 1 & \multicolumn{6}{|c|}{ IDENTIFIKASI TUGAS } \\
\hline A & $\begin{array}{l}\text { Hasil dari } \\
\text { pekerjaan }\end{array}$ & $\begin{array}{l}\text { Sesuai } \\
\text { dengan jenis } \\
\text { pekerjaan, } \\
\text { memotong } \\
\text { bahan } \\
\text { makanan, } \\
\text { menyiapkan } \\
\text { bahan } \\
\text { makanan dan } \\
\text { memasak }\end{array}$ & $\begin{array}{l}\text { Sesuai } \\
\text { dengan jenis } \\
\text { pekerjaan, } \\
\text { mencuci } \\
\text { peralatan } \\
\text { food and } \\
\text { beverages }\end{array}$ & $\begin{array}{l}\text { Sesuai } \\
\text { dengan jenis } \\
\text { pekerjaan, } \\
\text { responden } \\
\text { hanya } \\
\text { melakukan } \\
\text { pekerjaan } \\
\text { sebagai staff } \\
\text { cctv yang } \\
\text { meliputi } \\
\text { menjaga } \\
\text { monitor cctv, } \\
\text { reply back } \\
\text { cctv, dan } \\
\text { membantu } \\
\text { cek barang di } \\
\text { pos satpam }\end{array}$ & $\begin{array}{l}\text { Sesuai } \\
\text { dengan jenis } \\
\text { pekerjaan, } \\
\text { responden } \\
\text { hanya } \\
\text { melakukan } \\
\text { pekerjaan } \\
\text { sebagai staff } \\
\text { laundry yang } \\
\text { meliputi } \\
\text { melipat } \\
\text { linen, } \\
\text { menyetrika } \\
\text { linen dan } \\
\text { membantu } \\
\text { rekapitulasi } \\
\text { absensi } \\
\text { karyawan }\end{array}$ & $\begin{array}{l}\text { Sesuai } \\
\text { dengan jenis } \\
\text { pekerjaan, } \\
\text { mencuci } \\
\text { peralatan } \\
\text { food and } \\
\text { beverages }\end{array}$ \\
\hline B & $\begin{array}{l}\text { Prestasi yang } \\
\text { di dapat dari } \\
\text { pekerjaan }\end{array}$ & $\begin{array}{l}\text { The best } \\
\text { employee of } \\
\text { the month }\end{array}$ & Belum ada & Belum ada & Belum ada & $\begin{array}{l}\text { The best } \\
\text { employee of } \\
\text { the month }\end{array}$ \\
\hline 2 & \multicolumn{6}{|c|}{$\begin{array}{l}\text { VARIASI KETERAMPILAN } \\
\end{array}$} \\
\hline A & $\begin{array}{l}\text { Pekerjaan } \\
\text { yang } \\
\text { dilakukan }\end{array}$ & $\begin{array}{l}\text { Memotong } \\
\text { bahan } \\
\text { makanan, } \\
\text { menyiapkan } \\
\text { bahan } \\
\text { makanan dan } \\
\text { memasak }\end{array}$ & $\begin{array}{l}\text { mencuci } \\
\text { peralatan } \\
\text { food and } \\
\text { beverages }\end{array}$ & $\begin{array}{l}\text { responden } \\
\text { hanya } \\
\text { melakukan } \\
\text { pekerjaan } \\
\text { sebagai staff } \\
\text { cctv yang } \\
\text { meliputi } \\
\text { menjaga } \\
\text { monitor cctv, } \\
\text { reply back } \\
\text { cctv, dan } \\
\text { membantu } \\
\text { cek barang di } \\
\text { pos satpam }\end{array}$ & $\begin{array}{l}\text { responden } \\
\text { hanya } \\
\text { melakukan } \\
\text { pekerjaan } \\
\text { sebagai staff } \\
\text { laundry yang } \\
\text { meliputi } \\
\text { melipat } \\
\text { linen, } \\
\text { menyetrika } \\
\text { linen dan } \\
\text { membantu } \\
\text { rekapitulasi } \\
\text { absensi } \\
\text { karyawan }\end{array}$ & $\begin{array}{l}\text { mencuci } \\
\text { peralatan } \\
\text { food and } \\
\text { beverages }\end{array}$ \\
\hline B & $\begin{array}{l}\text { Ragam } \\
\text { pekerjaan } \\
\text { yang } \\
\text { dilakukan } \\
\end{array}$ & Sesuai SOP & Sesuai SOP & Sesuai SOP & Sesuai SOP & Sesuai SOP \\
\hline $\mathrm{C}$ & $\begin{array}{l}\text { Cara } \\
\text { melakukan } \\
\text { pekerjaan }\end{array}$ & Sesuai SOP & Sesuai SOP & Sesuai SOP & Sesuai SOP & Sesuai SOP \\
\hline D & Rotasi & Belum & Belum & Belum & Belum & Belum \\
\hline
\end{tabular}




\begin{tabular}{|c|c|c|c|c|c|c|}
\hline & pekerjaan & pernah & pernah & pernah & pernah & pernah \\
\hline 3 & \multicolumn{6}{|c|}{ SIGNIFIKASI TUGAS } \\
\hline A & $\begin{array}{l}\text { Pentingnya } \\
\text { pekerjaan bagi } \\
\text { karyawan }\end{array}$ & $\begin{array}{l}\text { Sangat } \\
\text { penting }\end{array}$ & $\begin{array}{l}\text { Sangat } \\
\text { penting }\end{array}$ & $\begin{array}{l}\text { Sangat } \\
\text { penting }\end{array}$ & $\begin{array}{l}\text { Sangat } \\
\text { penting }\end{array}$ & $\begin{array}{l}\text { Sangat } \\
\text { penting }\end{array}$ \\
\hline B & $\begin{array}{l}\text { Pengaruh } \\
\text { pekerjaan } \\
\text { untuk } \\
\text { karyawan }\end{array}$ & $\begin{array}{l}\text { Sangat } \\
\text { berpengaruh }\end{array}$ & $\begin{array}{l}\text { Sangat } \\
\text { berpengaruh }\end{array}$ & $\begin{array}{l}\text { Sangat } \\
\text { berpengaruh }\end{array}$ & $\begin{array}{l}\text { Sangat } \\
\text { berpengaruh }\end{array}$ & $\begin{array}{l}\text { Sangat } \\
\text { berpengaruh }\end{array}$ \\
\hline 4 & \multicolumn{6}{|c|}{ OTONOMI } \\
\hline A & $\begin{array}{l}\text { Strategi } \\
\text { pribadi yang } \\
\text { digunakan } \\
\text { dalam } \\
\text { melakukan } \\
\text { tugas } \\
\end{array}$ & Tidak ada & Tidak ada & Tidak ada & Tidak ada & Tidak ada \\
\hline B & $\begin{array}{l}\text { Improvisasi } \\
\text { tugas selain } \\
\text { dari SOP }\end{array}$ & Tidak ada & Tidak ada & Tidak ada & Tidak ada & Tidak ada \\
\hline 5 & \multicolumn{6}{|c|}{ UMPAN BALIK } \\
\hline A & $\begin{array}{l}\text { Penilaian baik } \\
\text { atau tidak } \\
\text { tugas yang } \\
\text { sudah } \\
\text { dilakukan }\end{array}$ & $\begin{array}{l}\text { Ada, dalam } \\
\text { bentuk } \\
\text { formulir } \\
\text { evaluasi }\end{array}$ & $\begin{array}{l}\text { Ada, dalam } \\
\text { bentuk } \\
\text { formulir } \\
\text { evaluasi }\end{array}$ & $\begin{array}{l}\text { Ada, dalam } \\
\text { bentuk } \\
\text { formulir } \\
\text { evaluasi }\end{array}$ & $\begin{array}{l}\text { Ada, dalam } \\
\text { bentuk } \\
\text { formulir } \\
\text { evaluasi }\end{array}$ & $\begin{array}{l}\text { Ada, dalam } \\
\text { bentuk } \\
\text { formulir } \\
\text { evaluasi }\end{array}$ \\
\hline B & $\begin{array}{l}\text { Informasi baik } \\
\text { buruk tentang } \\
\text { pekerjaan } \\
\text { yang sudah } \\
\text { dilakukan }\end{array}$ & $\begin{array}{l}\text { Ada, dalam } \\
\text { bentuk } \\
\text { appraisal } \\
\text { dengan } \\
\text { Department } \\
\text { Coordinator }\end{array}$ & $\begin{array}{l}\text { Ada, dalam } \\
\text { bentuk } \\
\text { appraisal } \\
\text { dengan } \\
\text { Department } \\
\text { Coordinator }\end{array}$ & $\begin{array}{l}\text { Ada, dalam } \\
\text { bentuk } \\
\text { appraisal } \\
\text { dengan } \\
\text { Department } \\
\text { Coordinator }\end{array}$ & $\begin{array}{l}\text { Ada, dalam } \\
\text { bentuk } \\
\text { appraisal } \\
\text { dengan } \\
\text { Department } \\
\text { Coordinator }\end{array}$ & $\begin{array}{l}\text { Ada, dalam } \\
\text { bentuk } \\
\text { appraisal } \\
\text { dengan } \\
\text { Department } \\
\text { Coordinator }\end{array}$ \\
\hline
\end{tabular}

Sumber: wawancara mendalam penulis (2019):

Dalam pembahasan karakteristik pekerjaan ini, dijelaskan hasil dari variabel karakteristik pekerjaan pada masing-masing responden karyawan disabilitas, yang dijelaskan sebagai berikut:

Karakteristik pekerjaan menyatakan bahwa hasil dari pekerjaan dikerjakan sesuai dengan jeni s pekerjaan masing-masing, sebagian dari karyawan penyandang disabilitas memiliki prestasi berupa best employee, prestasi ini didapatkan oleh karyawan penyandang disabilitas dengan jenis kecacatan Tuna Rungu.

Semua ragam pekerjaan yang dilakukan sudah sesuai dengan Standart Operasional Procedure (SOP), semua karyawan belum pernah mengalami rotasi pekerjaan selama bekerja di Nusa Dua Beach Hotel and Spa, pekerjaan yang dimiliki oleh karyawan sangat penting bagi karyawan, tidak ada strategi yang di pakai karyawan dalam menjalankan tugas, tidak ada improvisasi tugas selain aturan dalam Standart Operasional Procedure (SOP), ada sistem penilaian yang diberikan kepada karyawan berupa lembar evaluasi appraisal, dan semua karyawan mendapatkan informasi baik dan buruk tentang pekerjaan yang dilakukan. Dari hasil prestasi yang didapatkan serta berjalannya evaluasi yang diperoleh karyawan Penyandang Disabilitas hal ini mendukung adanya peningkatan kinerja bagi karyawan untuk memperbaiki pekerjaan yang buruk sebelumnya. Standart Operasional Procedure (SOP) menjadi landasan responden untuk melakukan pekerjaan, dengan 
adanya SOP ini menjadi informasi tambahan bagi karyawan untuk mengetahui pekerjaan apa saja yang harus dilakukan dan bagaimana cara melakukanya.

\subsection{Motivasi Kerja Karyawan Disabilitas di Nusa Dua Beach Hotel and Spa. \\ 3.4.1 Motivasi Intrinsik Karyawan}

Motivasi yang berasal dari dalam diri seseorang dapat mempengaruhi kualitas pekerjaan dan tindakan dalam melakukan pekerjaan tersebut, motivasi ini dinamakan motivasi intrinsik, dalam responden yang sudah diwawancarai dapat diketahui motivasi intrinsik dari masing-masing responden yaitu, sebagai berikut:

1. Responden pertama bernama Ni Luh Putu Sri Arminingsih, bekerja di Food and Beverage Department sebagai staff cook, dengan jenis kecacatan yaitu Tuna Rungu. Responden pertama memiliki kualitas kerja yang baik selama bekerja di Nusa Dua Beach Hotel and Spa, responden memiliki kemauan untuk semangat berprestasi serta memiliki keinginan untuk diakui keberadaan dan kemampuannya dalam bekerja. Responden memiliki rasa tanggung jawab yang tinggi dalam melakukan pekerjaan dengan resiko pekerjaan yang dialami sebagai staff cook berupa terkena cairan minyak panas saat bekerja. Responden juga diperlengkapi dengan pelatihan-pelatihan yang diberikan pihak perusahaan untuk menunjang kualitas karyawan berupa training aktivitas karyawan sebagai staff cook dan pelatihan fire drill untuk karyawan. Untuk pekerjaan yang dimiliki oleh responden saat ini, sudah sesuai dengan minat dan kemampuan serta responden merasakan pentingnya bekerja yang dapat membantu kehidupan dari responden. Pekerjaan saat ini sesuai dengan keinginan sendiri, walaupun dahulu pernah bekerja di section lain yaitu pastry, responden berpindah section dikarenakan kurang nyaman dengan lingkungan kerja dan cara kerja di section pastry yang lebih sibuk daripada section kantin.

2. Responden kedua bernama I Wayan Merta Yasa, bekerja di Food and Beverage Department sebagai staff steward, dengan jenis kecacatan yaitu Tuna Rungu. Responden kedua memiliki kualitas kerja yang baik selama bekerja di Nusa Dua Beach Hotel and Spa, responden memiliki kemauan untuk semangat berprestasi dan semangat untuk bekerja dikarenakan kebutuhan ekonomi sebagai tulang punggung keluarga, serta memiliki keinginan untuk diakui keberadaan dan kemampuannya dalam bekerja. Responden memiliki rasa tanggung jawab yang tinggi dalam melakukan pekerjaan dengan resiko pekerjaan yang dialami sebagai staff steward yaitu piring pecah, luka sobek akibat tergores kaca piring atau gelas yang pecah, jatuh di lingkungan kerja akibat lingkungan kerja yang licin. Responden juga diperlengkapi dengan pelatihanpelatihan yang diberikan pihak hotel untuk menunjang kualitas karyawan berupa training aktivitas karyawan tata cara menjadi steward dan pelatihan fire drill untuk karyawan. Untuk pekerjaan yang dimiliki oleh responden saat ini, sudah sesuai deng an minat dan kemampuan serta responden merasakan pentingnya bekerja yang dapat membantu kehidupan dari responden. Pekerjaan saat ini sesuai dengan keinginan sendiri, walaupun ada keinginan untuk pindah departemen di Housekeeping Department pada bagian room attendant.

3. Responden ketiga bernama I Wayan Merta, bekerja di Security Department bagian $C C T V$, dengan jenis kecacatan yaitu Tuna Daksa. Responden ketiga memiliki kualitas kerja yang baik selama bekerja di Nusa Dua Beach Hotel and Spa, responden memiliki kemauan dan semangat untuk semangat berprestasi serta memiliki keinginan untuk diakui keberadaan dan kemampuannya dalam bekerja walaupun memiliki keterbatasan. Responden memiliki rasa tanggung jawab yang tinggi dalam melakukan pekerjaan sesuai dengan ruang lingkup pekerjaan dengan resiko pekerjaan yang dialami sebagai CCTV staff. Responden juga diperlengkapi dengan pelatihan-pelatihan yang diberikan pihak perusahaan untuk menunjang kualitas karyawan berupa training aktivitas karyawan sebagai staff CCTV yaitu penggunaan alat CCTV dan pelatihan fire drill untuk karyawan dimana pelatihan ini tidak hanya penting ketika aktivitas pekerjaan tetapi juga dalam kehidupan sehari-hari selain di tempat kerja. Untuk pekerjaan yang 
dimiliki oleh responden saat ini sudah sesuai dengan minat dan kemampuan responden, yang mana responden merasakan pentingnya bekerja yang dapat membantu menunjang biaya kehidupan responden serta pekerjaan ini sangat penting dikarenakan kecilnya lingkup pekerjaan penyandang disabilitas dan keterbatasa penyandang disabilitas dalam aktivitas pekerjaan terutama pada penyandang disabilitas Tuna Daksa dalam mendapatkan pekerjaan yang sama dengan non disabilitas. Pekerjaan saat ini sudah sesuai dengan keinginan sendiri.

4. Responden keempat bernama Putu Sri Agustini, bekerja di Housekeeping Department sebagai staff laundry, dengan jenis kecacatan yaitu Tuna Rungu. Responden keempat memiliki kualitas kerja yang baik selama bekerja di Nusa Dua Beach Hotel and Spa, responden memiliki kemauan untuk semangat berprestasi serta memiliki keinginan untuk diakui keberadaan dan kemampuannya dalam bekerja. Responden memiliki rasa tanggung jawab yang tinggi dalam melakukan pekerjaan dengan resiko pekerjaan yang dialami sebagai staff laundry berupa kondisi lingkungan kerja yang panas, linen at au handuk yang mudah robek, rawan terkena alat setrika. Responden juga diperlengkapi dengan pelatihan-pelatihan yang diberikan pihak perusahaan untuk menunjang kualitas karyawan berupa training aktivitas karyawan sebagai staff laundry dan pelatihan fire drill untuk karyawan. Untuk pekerjaan yang dimiliki oleh responden saat ini, sudah sesuai dengan minat dan kemampuan serta responden merasakan pentingnya bekerja yang dapat membantu kehidupan dari responden. Pekerjaan saat ini sesuai dengan keinginan sendiri, walaupun responden memiliki keinginan untuk kembali lagi pada section florist, akan tetapi dikarenakan lokasi lingkungan kerja florist di lantai 3, responden lelah untuk naik turun dan dikarenakan pengalaman supranatural atau mistis yang pernah dialmi oleh responden saat dulu bekerja di bagian florist, membuat responden takut dan mengurangi minat untuk kembali lagi menjadi staff di bagian florist.

5. Responden kelima bernama I Wayan Endra Wijaya, bekerja di Food and Beverage Department sebagai staff steward, dengan jenis kecacatan yaitu Tuna Rungu. Responden kelima memiliki kualitas kerja yang baik selama bekerja di Nusa Dua Beach Hotel and Spa, responden memiliki kemauan untuk semangat berprestasi lebih dari sebelumnya, dengan prestasi yang sudah dimiliki, responden mempunyai keinginan untuk terus berprestasi dalam pekerjaan, hal ini juga disebabkan oleh prestasi yang telah di dapatkan sebelumnya dan semangat untuk bekerja dikarenakan kebutuhan ekonomi sebagai kepala keluarga, serta memiliki keinginan untuk diakui keberadaan dan kemampuannya dalam bekerja yang kondisinya sama dengan karyawan lainnya tanpa ada stigma yang buruk tentang karyawan disabilitas. Responden memiliki rasa tanggung jawab yang tinggi dalam melakukan pekerjaan dengan resiko pekerjaan yang dialami sebagai staff steward yaitu piring pecah, luka sobek akibat tergores kaca piring atau gelas yang pecah, jatuh di lingkungan kerja akibat lingkungan kerja yang licin. Responden juga diperlengkapi dengan pelatihanpelatihan yang diberikan pihak hotel untuk menunjang kualitas karyawan berupa training aktivitas karyawan tata cara menjadi steward dan pelatihan fire drill untuk karyawan. Untuk pekerjaan yang dimiliki oleh responden saat ini, sudah sesuai dengan minat dan kemampuan serta responden merasakan pentingnya bekerja yang dapat membantu kehidupan dari responden. Pekerjaan saat ini sesuai dengan keinginan sendiri, responden tidak memiliki keinginan untuk berpindah departemen dikarenakan sudah nyaman dengan fasilitas dan gaji yang diberikan kepada responden.

Seluruh responden bekerja sesuai dengan keinginan sendiri tanpa ada paksaan dari luar, keinginan bekerja ini juga sejalan dengan keinginan diakui keberadaanya dan diakui kemampuanya walaupun responden memiliki perbedaan kemampuan dengan karyawan non penyandang disabilitas. Dalam hal ini responden menyesuaikan diri dengan lingkungan, salah satu cara menyesuaikan diri dengan lingkungan yaitu dengan bekerja sesuai Standart Operational Prosedure. Kemampuan responden untuk bekerja sesuai SOP menjadikan beberapa dari responden memiliki prestasi dalam bekerja yaitu menajdi The Best employee of The Month. 


\subsubsection{Motivasi Ekstrinsik Karyawan}

Motivasi ekstrinsik merupakan motivasi yang berasal dari luar diri seseorang yang dapat mempengaruhi kualitas pekerjaan dan tindakan dalam melakukan pekerjaan tersebut. Dalam responden yang sudah diwawancarai maka dapat diketahui motivasi ekstrinsik dari masing-masing responden yaitu, sebagai berikut:

1. Responden pertama bernama Ni Luh Putu Sri Arminingsih, bekerja di Food and Beverage Department sebagai staff cook, dengan jenis kecacatan yaitu Tuna Rungu. Responden pertama melakukan pekerjaan berdasarkan dengan Standard Operasional Prosedur, dalam pengawasan pekerjaan Human Resources Departemen sebagai departemen sumber daya manusia mengawasi perkembangan karyawan dengan baik dan puas dengan hasil kerja responden pada pekerjaan yang dilakukan. Hubungan karyawan disabilitas dengan karyawan lainnya terjalin baik walaupun terdapat keterbatasan komunikasi. Untuk komunikasi dengan karyawan non penyandang disabilitas, responden menggunakan bahasa isyarat, tulisan pada gawai ataupun kertas dan dengan melihat oral bibir. Untuk kondisi lingkungan kerja responden yang bekerja pada departemen kitchen pada saat ini sangat mendukung aktivitas kerja responden dikarenakan lokasi yang nyaman dan jenis pekerjaan yang mudah untuk dilakukan oleh responden. Sedangkan untuk membantu aktivitas responden dalam kondisi penyandang disabilitas yang dimiliki, responden mempunyai alat bantu dengar, akan tetapi tidak digunakan saat bekerja dikarenakan kondisi lingkungan yang panas dan dekat api sehingga berpengaruh pada kenyaman pemakaian alat bantu dengar yang digunakan oleh responden. Untuk upah yang diterima sudah sesuai dengan keinginan dan posisi pekerjaan yang dimiliki oleh responden. Dalam posisi kerja, responden belum memiliki keinginan untuk berpindah departemen karena sudah nyaman dengan lingkungan kerja saat ini dan belum memiliki keinginan untuk naik jabatan.

2. Responden kedua bernama I Wayan Merta Yasa, bekerja di Food and Beverage Department sebagai staff steward, dengan jenis kecacatan yaitu Tuna Rungu. Responden kedua melakukan pekerjaan berdasarkan dengan Standard Operasional Prosedur dan akan ada tambahan jika diperintahkan oleh kepala departemen. Dalam pengawasan pekerjaan Human Resources Departemen sebagai departemen sumber daya manusia mengawasi perkembangan karyawan dengan baik dan memberikan evaluasi kebersihan, evaluasi hasil kerja responden pada pekerjaan yang dilakukan. Hubungan karyawan disabilitas dengan karyawan lainnya terjalin baik walaupun terdapat keterbatasan komunikasi. Untuk komunikasi dengan karyawan non penyandang disabilitas, responden menggunakan tulisan pada gawai ataupun kertas dan gerakan tangan. Untuk kondisi lingkungan kerja responden yang bekerja pada departemen food and beverages pada saat ini sangat mendukung aktivitas kerja responden dikarenakan lokasi yang nyaman dan jenis pekerjaan yang mudah untuk dilakukan oleh responden serta adanya kordinator yang baik dan rinci dalam mengkordinir. Sedangkan untuk membantu aktivitas responden dalam kondisi penyandang disabilitas yang dimiliki, responden tidak memiliki alat bantu dengar. Untuk upah dan benefit lainnya dalam bekerja sudah sesuai dengan keinginan dan posisi pekerjaan yang dimiliki oleh responden dan masa kerja responden. Dalam masa kerja saat ini, responden kedua belum memiliki keinginan untuk pindah tempat kerja ataupun berpindah pada departemen lainnya serta belum memiliki keinginan untuk naik jabatan.

3. Responden ketiga bernama I Wayan Merta, bekerja di Security Department pada staff $C C T V$ dengan jenis kecacatan yaitu Tuna Daksa. Responden ketiga melakukan pekerjaan berdasarkan dengan Standard Operasional Prosedur dan akan ada tambahan jika diperintahkan oleh kepala departemen. Dalam pengawasan pekerjaan Human Resources Departemen sebagai departemen sumber daya manusia mengawasi perkembangan karyawan dengan baik dan memberikan kepedulian serta perhatian lebih dalam pengawasan untuk karyawan penyandang disabilitas. Hubungan karyawan disabilitas dengan karyawan lainnya terjalin baik. Untuk komunikasi dengan karyawan 
non penyandang disabilitas, responden menggunakan bahasa komunikasi biasa dan tidak ada kesenjangan pada masing-masing karyawan. Untuk kondisi lingkungan kerja responden yang bekerja pada departemen security pada saat ini sangat mendukung aktivitas kerja responden dikarenakan lokasi yang nyaman dan jenis pekerjaan yang sesuai untuk dilakukan oleh responden serta adanya kordinator yang baik dan rinci dalam mengkordinir. Sedangkan untuk membantu aktivitas responden dalam kondisi penyandang disabilitas yang dimiliki, responden memiliki alat bantu yaitu kursi roda yang dimiliki oleh responden, tanpa diberikan oleh pihak hotel, selain itu fasilitas jalan dan aksesibilitas pada hotel yang sudah mendukung aktvitas kerja penyandang disabilitas Tuna Daksa. Untuk upah dan benefit lainnya dalam bekerja sudah sesuai dengan keinginan, masa kerja dan posisi pekerjaan yang dimiliki oleh responden.

Dalam masa kerja saat ini, responden keempat belum memiliki keinginan untuk pindah tempat kerja ataupun berpindah pada departemen lainnya serta belum memiliki keinginan untuk naik jabatan dikarenakan kondisi responden yang dirasakan responden belum mendukung untuk naik jabatan pada departemen saat ini yang mana aktivitas kerja belum dapat dipenuhi oleh responden karena kondisi fisik penyandang disabilitas.

4. Responden keempat bernama Putu Sri Agustini, bekerja di Housekeeping Department sebagai staff laundry, dengan jenis kecacatan yaitu Tuna Rungu. Responden keempat melakukan pekerjaan berdasarkan dengan Standard Operasional Prosedur dan akan ada tambahan jika diperintahkan oleh kepala departemen. Dalam pengawasan pekerjaan Human Resources Departemen sebagai departemen sumber daya manusia mengawasi perkembangan karyawan dengan baik dan memberikan evaluasi kebersihan, evaluasi hasil kerja responden pada pekerjaan yang dilakukan. Hubungan karyawan disabilitas dengan karyawan lainnya terjalin baik, akan tetapi juga terdapat karyawa lainnya yang kurang baik denan responden dalam menjalin relasi, dikarenakan responden menyandang disabilitas, ada beberapa karyawan yang tidak pernah menjalin komunikasi dengan responden. Untuk komunikasi dengan karyawan non penyandang disabilitas, responden memahami dan berkomunikasi menggunakan tulisan pada gawai ataupun kertas dan oral atau gerak bibir. Untuk kondisi lingkungan kerja responden yang bekerja pada departemen housekeeping pada saat ini kurang mendukung aktivitas kerja responden dikarenakan lokasi yang panas akan tetapi jenis pekerjaan yang mudah menjadi faktor responden ke empat untuk bertahan bekerja di bagian departemen housekeeping. Sedangkan untuk membantu aktivitas responden ke empat, responden tidak memakai alat bantu dengar dikarenakan responden merasa tidak memerluka alat bantu dengar tersebut dalam bekerja. Untuk upah dan benefit lainnya dalam bekerja sudah sesuai dengan keinginan dan posisi pekerjaan yang dimiliki oleh responden. Dalam masa kerja saat ini, responden keempat memiliki keinginan berpindah pada section kerja lainnya yaitu pada section florist, akan tetapi responden masih bertahan pada section laundry dikarenakan adanya pengalaman mistis yang dialami oleh responden keempat yang mebuat responden keempat mengurungkan keinginan untuk berpindah section.

5. Responden kelima bernama I Wayan Endra Wijaya, bekerja di Food and Beverage Department sebagai staff steward, dengan jenis kecacatan yaitu Tuna Rungu. Responden kelima melakukan pekerjaan berdasarkan dengan Standard Operasional Prosedur dan akan ada tambahan jika diperintahkan oleh kepala departemen. Dalam pengawasan pekerjaan Human Resources Departemen sebagai departemen sumber daya manusia mengawasi perkembangan karyawan dengan baik dan memberikan evaluasi kebersihan, evaluasi hasil kerja responden pada pekerjaan yang dilakukan. Hubungan karyawan disabilitas dengan karyawan lainnya ada yang terjalin baik ada juga yang tidak dikarenakan terdapat keterbatasan komunikasi. Untuk komunikasi dengan karyawan non penyandang disabilitas, responden menggunakan tulisan pada gawai ataupun kertas dan gestur. Pada kondisi lingkungan kerja responden kelima yang bekerja pada departemen food and beverages saat ini sangat mendukung aktivitas kerja responden dikarenakan lokasi yang nyaman dan jenis pekerjaan yang mudah 
untuk dilakukan oleh responden serta adanya kordinator yang baik dan rinci dalam mengkordinir. Sedangkan untuk membantu aktivitas responden dalam bekerja, responden tidak memiliki alat bantu dengar sebagai alat yang mendukung aktivitas bekerja, hal ini dikarenakan ketidaknyamanan pemakaian alat dengan kondisi lingkungan kerja yang sempit dan udara yang panas. Untuk upah dan benefit lainnya dalam bekerja sudah sesuai dengan keinginan dan posisi pekerjaan yang dimiliki oleh responden. Dalam masa kerja saat ini, responden kelima belum memiliki keinginan untuk pindah te0mpat kerja ataupun berpindah pada departemen lainnya dikarenakan sudah berumur atau jenjang usia sudah tua, dan kesulitan mencari hotel lain, jika mendapatkan pekerjaan pada hotel lain, ada kemungkinan untuk gaji dimulai lagi dari bawah, berbeda dengan upah yang didapatkan sat ini di Nusa Dua Beach Hotel and Spa yang sudah cukup untuk memenuhi kebutuhan, responden kelima juga belum memiliki keinginan untuk naik jabatan.

Melalui pernyataan responden mengenai motivasi ekstrinsik, suasana lingkungan dalam pekerjaan menjadi motivasi responden dalam menjalani aktivitas pekerjaan. Karyawan di sekitar Nusa Dua Beach Hotel and Spa memahami komunikasi dengan karyawan penyandang disabilitas Tuna Rungu dan Tuna Wicara dengan gestur dan tulisan. Dari hal ini diketahui bahwa komunikasi berjalan dengan baik di lingkungan Nusa Dua Beach Hotel and Spa. Pembagian upah yang sesuai dengan posisi dan jabatan juga menjadi motivasi dari responden dalam bekerja. Seluruh responden yang berstatus karyawan kontrak dengan upah rata-rata UMR Badung dan fasilitas kesehatan bagi karyawan kontrak melalui BPJS Ketenagakerjaan merupakan motivasi untuk bisa memenuhi kebutuhan dan kepuasan responden dari hasil pekerjaan.

\subsection{Faktor Penghambat dan Pendukung Karyawan Penyandang Disabilitas dalam bekerja}

Dalam proses pengembangan karyawan terdapat faktor-faktor yang menghambat dan mendukung perkembangan karyawan sebagai sumber daya manusia yang sangat diperlukan pada perusahaan. Faktor penghambat dan pendukung ini dibagi berdasarkan faktor individu dan faktor manajemen pada karyawan penyandang disabilitas di Nusa Dua Beach Hotel and Spa. Faktor pendukung dan penghambat pada karyawan penyandang disabilitas di Nusa Dua Beach Hotel and Spa dalam bekerja dibagi sebagai berikut:

1) Faktor Pendukung

Pada Faktor individu, dijelaskan faktor pendukung kinerja karyawan penyandang disabilitas adalah sebagai berikut :

(1). Pendidikan dan skill,

Merupakan faktor pendukung pada karyawan penyandang disabilitas. Untuk seluruh karyawan penyandang disabilitas memiliki pendidikan minimal SMA-LB dan berasal dari sekolah dan yayasan yang sama. Skill yang dimiliki oleh masing-masing karyawan penyandang disabilitas sesuai dengan pekerjaan mereka saat ini dan latar belakang pendidikan. Skill yang dimiliki oleh karyawan tidak hanya berasal dari latar belakang pendidikan tetapi juga secara rutin satu bulan sekali karyawan mengikuti training di hotel untuk meningkatkan kemampuan di maisng-masing bidang pekerjaan karyawan penyandang disabilitas.

\section{(2). Prestasi}

Adanya prestasi yang diperoleh oleh beberapa karyawan penyandang disabilitas sebagai the best employee of the moon dikarenakan hasil kerja yang memuaskan, memberikan peranan untuk mendukung semangat kinerja dari karyawan penyandang disabilitas untuk terus berkembang terutama untuk tetap mendapatkan prestasi dengan hasil kinerja sesuai departemen masing-masing. David C. Mc. Cleland (1997) seperti dikutip Mangkunegara (2001:68), menyatakan bahwa ada hubungan yang positif antara motif berprestasi dengan pencapaian kerja". Motif berprestasi adalah suatu dorongan dalam diri seseorang untuk melakukan suatu kegiatan atau tugas dengan sebaik-baiknya agar mampu mencapai prestasi kerja dengan predikat terpuji. 
(3). Kebutuhan

Bagi karyawan penyandang disabilitas yang menikah dan yang belum menikah memiliki kebutuhan berbeda terutama dalam hal materiil. Kebutuhan menjadi faktor pendukung karyawan untuk bekerja karena adanya pengeluaran sehari-hari dan membiayai keluarga. Bagi karyawan penyandang disabilitas yang sudah menikah, kebuthan materiil berupa pembiayaan bagi kebutuhan anggota keluarga lainnya yang belum bekerja, atau untuk menambah penghasilan pasangan untuk kehidupan rumah tangga. Bagi karyawan penyandang disabilitas yang belum menikah, kebutuhan materiil digunakan untuk mendukung ekonomi orang tua dan kebutuhan individu sehari-hari, selain sandang, pangan dan papan, kebutuhan hiburan juga menjadi faktor pendukung karyawan penyandang disabilitas bekerja. Dari hal ini juga diketahui bahwa, rata-rata ekonomi pkaryawan penyandang disabilitas berada pada penghasilan ekonomi rata-rata menengah ke bawah. Selain kebutuhan secara materiil, kebutuhan secara moral jugamenjadi faktor pendukung yaitu dengan adanya kebutuhan untuk diakui keberadaanya dan diakui kemampuanya oleh karyawan lainnya berperan meningkatkan motivasi instrinsik dari masing-masing karyawan penyandnag disabilitas untuk terus berkarya dan mengembangkan diri dengan bekerja di Nusa Dua Beach Hotel and Spa.

(4). Kemudahan pekerjaan yang dilakukan

Pada pekerjaan yang dilakukan masing-masing karyawan penyandang disabilitas mengakui bahwa mereka memilih pekerjaan sesuai dengan minat dna kemampuan kerja mereka. Kemudahan dalam melakukan pekerjaan yang dilakukan menjadi pendukung karyawan untuk mau melakukan pekerjaan tersebut. Rata-rata pekerjaan yang dilakukan adalah pekerjaan pemula pada departemen masing-masing yang memiliki resiko lebih kecil daripada jenis pekerjaan lainnya.

Kemudian pada Faktor Manajemen yang berasal dari lingkungan kerja karyawan penyandang disabilitas di Nusa Dua Beach Hotel and Spa, dijelaskan faktor pendukung sebagai berikut :

(1). Gaji dan Upah

Bagi karyawan penyandang disabilitas, pengupahan yang diberikan oleh Nusa Dua Beach Hotel and Spa sudah sesuai dengan masing-masing pekerjaan dan posisi karyawan penyandang disabilitas saat ini. Gaji yang diberikan berupa upah minimum tenaga kerja di kabupaten Badung, dan adanya fasilitas kesehatan berupa BPJS Ketenagakerjaan yang mendukung kesehatan dan keselamatan kerja karyawan penyandang disabilitas selama bekerja di Nusa Dua Beach Hotel and Spa.

(2) Hubungan dengan sesama karyawan

Hubungan yang terjalin dengan sesama karyawan penyandang disabilitas maupun non penyandang disabilitas dapat terjalin dengan baik. Karyawan non penyandnag disabilitas dapat menghargai dan memperlakukan karyawan penyandang disabilitas sama dengan karyawan non penyandang disabilitas tanpa adanya keistimewaan lainnya ataupun perlakuan khusus lainnya. Lingkungan yang saling mendukung untuk bekerja ini menjadikan karyawan penyandang disabilitas dapat melakukan pekerjaan dengan maksimal.

(3). Adanya Standart Operational Procedure, pelatihan dan evaluasi dari pimpinan serta pihak manajemen.

Tuntunan pekerjaan lewat Standart Operational Procedure (SOP) pada Nusa Dua Beach Hotel and Spa membuat karyawan penyandnag disabilitas memahami arahan bekerja dan pekerjaan apa saja yang harus dilakukan. Hal ini membantu pemahaman karyawan penyandnag disabilitas untuk melakukan pekerjaan masing-masing seusai dengan SOP hotel. Selain itu, adanya evaluasi yang diberikan pihak manajemen hotel lewat pemimpin pada maisng-masing departemen dapat menunjang skill dan memperbaiki kesalahan yang pernah dilakukan atau kekurangan dalam bekerja sehingga pekerjaan dapat dilakukan lebih baik lagi dan maksimal. 
2). Faktor Penghambat

Dalam faktor individual yang menghambat karyawan penyandnag disabilitas dalam bekerja, adalah sebagai berikut :

(1). Komunikasi

Pada karyawan penyandang disabilitas Tuna Rungu, keterbatasan komunikasi menjadi penghambat karyawan penyandang disabilitas Tuna Rungu untuk dapat memahami karyawan lainnya, atau instruksi dari pimpinan. Hambatan komunikasi ini berupa keterbatasan pemahaman bahasa pada karyawan penyandang disabilitas Tuna Rungu sehingga dalam komunikasi dilakukan dengan perantara tulisan dan gerakan gestur tubuh dan oral wajah.

(2). Kesehatan Jiwa dan Fisik

Keterbatasan fisik yang dimiliki oleh karyawan penyandang disabilitas menjadi penghambat karyawan penyandang disabilitas untuk bergerak lebih leluasa dan mengembangkan diri lebih leluasa dibandingkan dengan karyawan non penyandang disabilitas lainnya yang memiliki fisik dan jiwa yang normal. Bagi karyawan penyandang disabilitas Tuna Daksa, keterbatasan dalam ruang gerak yang hanya bisa dibantu oleh al at bantu kursi roda membuat karyawan ini hanya bisa bergerak pada lingkup kerjanya saja yaitu pada bagian ruang CCTV sebagai pengawas CCTV tanpa adanya tambahan ruang gerak lainnya yang sesuai dengan departemenya Security.

Kemudian pada Faktor Manajemen terdapat Faktor Penghambat sebagai berikut :

(1). Tidak adanya rotasi pekerjaan

Rotasi Pekerjaan merupakan perpindahan karyawan secara sistematis dari satu pekerjaan ke pekerjaan lainnya. Tidak adanya rotasi pekerjaan yang dialami oleh karyawan penyandang disabilitas membuat karyawan penyandang disabilitas hanya mengembangkan diri pada satu bidang saja, sehingga kurangnya kreatifitas dan improvisasi yang dilakukan oleh karyawan penyandnag disabilitas. Hal ini dapat memicu semangat dalam bekerja padam. Ada beberapa dari karyawan penyandang disabilitas yang menginginkan rotasi pekerjaan, akan tetapi ada beberpa hal yang menghambat yaitu kepemimpinan dari bidang yang akan dituju tidak sesuai dengan budaya kerja yang di inginkan oleh karyawan, serta lokasi bidang yang di inginkan oleh karyawan membuat karyawan lelah untuk bergerak lebih.

\section{Ucapan terima kasih}

Puji Syukur penulis panjatkan kepada Tuhan Yang Maha Esa karena kasih-Nya penulis dapat menyelesaikan laporan akhir dengan judul "Karakteristik dan Motivasi Penyandang Disabilitas Sebagai Karyawan di Nusa Dua Beach Hotel and Spa".

Penulisan ini mendapatkan banyak bantuan dan dukungan serta bimbingan dari berbagai pihak sehingga dengan kerendahan hati penulis menyampaikan ucapan terimakasih sebesar-besarnya kepada orang tua dan keluarga, pihak Manajemen Nusa Dua Beach Hotel and Spa, dosen pembimbing, teman-teman, serta seluruh dosen dan staff Fakultas Pariwisata Universitas Uday ana yang sudah membantu secara materi maupun materiil.

\section{DAFTAR PUSTAKA}

Hasibuan Malayu. Manajemen Sumber Daya Manusia. PT Bumi Aksara. Jakarta. 2006

Irmawati Aida. 2015. Peran Human Resources Development Dalam Meningkatkan Produktivitas Karyawan Di PT. Yanasurya Bhaktipersada. Malang. Jurnal Aplikasi Administrasi STIE Indonesia Malang. Vol.18. No. 2

Istijanto. Riset Sumber Daya Manusia. PT Gramedia Pustaka Utama. Jakarta. 2005 
Maulana Hazra. 2015. Pengaruh Motivasi Intrinsik, Motivasi Ekstrinsik Dan Komitmen Organisasi Terhadap Kinerja Karyawan Pada Bank BTN Kantor Cabang Malang. Malang:

Jurnal Administrasi Bisnis Universitas Brawijaya.

Moneysmart. (2019, 18 Maret). Ini Penyumbang Devisa Nomor Dua Terbesar Indonesia, Nilainya Rp. 246 Triliun. Diperoleh 18 Mei 2019, dari moneysmart.id/pariwisata-salah-satumotor-penyumbang-devisa-indonesia/

NusaBali.com (2018. 17 Februari). Industri Pariwisata Tetap Andalan Penyerapan Naker. Diperoleh 18 Mei 2019, dari nusabali.com/berita/25695/industri-pariwisata-tetapandalan-penyerapan-naker.

Prasetyo Yudhi. 2016. Motivasi Kerja Orang Penyandang Disabilitas yang Berada di YPCM Yogyakarta. Yogyakarta: Jurnal Fakultas Psikologi Universitas Ahmad Dahlan Yogyakarta.

Purwanta Adi, Setia. Vulnerable. Jakarta, 2013

Putra Aditya, Kamajaya. 2013. Pengaruh Motivasi Intrinsik Dan Motivasi Ekstrinsik Terhadap Kepuasan Kerja. Surabaya. Jurnal Ilmu Manajemen Universitas Negeri Surabaya. Vol 1. No 1.

Ririn, Indriani. 2017 "Penyandang Disabilitas Juga Bisa Bekerja di Dunia Perhotelan" https://www.google.com/amp/s/amp.suara.com/lifestyle/2017/04/20/153942/penya ndang-disabilitas-juga-bisa-bekerja-di-dunia-perhotelan

Sakinah, Ummu. 2016 "Mengapa Partisipasi Penyandang Disabilitas Dalam Bursa Tenaga Kerja Minim?" https://www.google.com/amp/s/amp.rappler.com/indonesia/berita/155758-sebabsolusi-partisipasi-penyandang-disabilitas-tenaga-kerja

Subyantoro Arief. 2009. Karakteristik Individu, Karakteristik Pekerjaan, Karakteristik Organisasi dan Kepuasan Kerja Pengurus yang Dimediasi oleh Motivasi Kerja (Studi pada Pengurus KUD di Kabupaten Sleman). Sleman: Jurnal Manajemen dan Kewirausahaan Fakultas Ekonomi UPN Veteran. Vol 11. No 1.

Suwena, Widyatmaja. Pengetahuan Dasar Ilmu Pariwisata. Pustaka Larasan. Denpasar. 2017.

Undang-Undang Nomor 8 Tahun 2016 tentang Penyandang Disabilitas

Valentini Kalargyrou. 2012. People with disabilities : A new model of productive labor. Amerika Serikat: Hosppitality Management Scholarship in University of New Hampshire Scholar Repository 